\title{
Oxidant-induced cardiomyocyte injury: Identification of the cytoprotective effect of a dopamine 1 receptor agonist using a cell-based high-throughput assay
}

\author{
DOMOKOS GERÖ ${ }^{1}$, KATALIN MÓDIS ${ }^{1}$, NÓRA NAGY ${ }^{1}$, PETRA SZOLECZKY ${ }^{1}$, \\ ZOLTÁN DÓRI TÓTH ${ }^{1}$, GYÖRGY DORMÁN ${ }^{2}$ and CSABA SZABÓ ${ }^{1,3}$ \\ ${ }^{1}$ CellScreen Applied Research Center, Semmelweis University Medical School; ${ }^{2}$ AMRI, Budapest, Hungary; \\ ${ }^{3}$ Department of Surgery, University of Medicine and Dentistry of New Jersey, Newark, NJ, USA
}

Received June 7, 2007; Accepted July 30, 2007

\begin{abstract}
Myocyte injury due to myocardial reperfusion injury plays a crucial role in the pathogenesis of acute myocardial infarction even after successful coronary revascularization. Identification of compounds that reduce reperfusionassociated myocyte death is important. Therefore, we developed an in vitro model of myocardial reperfusion injury in $\mathrm{H} 9 \mathrm{c} 2$ rat cardiomyocytes and applied a cell-based high-throughput approach to screen a standard library of pharmacologically active compounds (LOPAC) in order to identify drugs with cardioprotective effects. Oxidative stress was induced with hydrogen peroxide $\left(\mathrm{H}_{2} \mathrm{O}_{2}\right)$ treatment, which resulted in $\sim 50 \%$ reduction in cell viability. Test compounds were added at a $3-\mu \mathrm{M}$ final concentration as a pretreatment or in a delayed fashion (30 min after the peroxide challenge in order to imitate pharmacological treatment following angioplasty). Cells were cultured for 3 or $24 \mathrm{~h}$. Viability was quantitated with the methylthiazolyldiphenyl-tetrazolium bromide method. Cytotoxicity and cytoprotection were also evaluated by measuring the lactate dehydrogenase activity in the cell culture supernatant. The screening identified a number of compounds with cytoprotective action, including molecules that are known
\end{abstract}

Correspondence to: Dr Csaba Szabó, CellScreen Applied Research Center, Semmelweis University Medical School, Üllöi út 93, Budapest, H-1091, Hungary

E-mail: szabocsaba@aol.com

Abbreviations: APB, 7,8-dihydroxy-3-allyl-1-phenyl-2,3,4,5tetrahydro-1H-3-benzazepine; DMEM, Dulbecco's modified Eagle's medium; DMSO, dimethyl sulfoxide; $\mathrm{H}_{2} \mathrm{O}_{2}$, hydrogen peroxide; HRP, horseradish peroxidase; LDH, lactate dehydrogenase; LOPAC, library of pharmacologically active compounds; MTT, methylthiazolyldiphenyl-tetrazolium bromide; PAR, poly(ADP-ribose); PARP, poly(ADP-ribose) polymerase; PBS, phosphate buffered saline; PJ34, N-(-oxo-5,6-dihydro-phenanthridin-2-yl)-N,Ndimethylacetamide $\mathrm{HCl}$

Key words: cell necrosis, apoptosis, oxidative stress, poly(ADPribose) polymerase, myocardial infarction, high-throughput screening, high content screening to interfere with components of DNA repair and cell cycle progression, e.g. poly(ADP-ribose) polymerase (PARP) inhibitors, topoisomerase inhibitors, and cyclin dependent kinase inhibitors, or reduce energy consumption by interfering with cardiac myofilament function. A number of dopamine D1 receptor agonists also provided significant cytoprotection at $3 \mathrm{~h}$, but only three of them showed a similar effect at $24 \mathrm{~h}$ : chloro- and bromo-APB and chloro-PB hydrobromide. ChloroAPB hydrobromide significantly reduced peroxide-induced PARP activation in the myocytes independently of its action on dopamine D1 receptors, but lacked PARP inhibitor capacity in a cell-free PARP assay system. In conclusion, the pattern of cytoprotective drugs identified in the current assay supports the overall validity of our model system. The findings demonstrate that cytoprotective agents, including novel indirect inhibitors of cellular PARP activation can be identified with the method, chloro-APB hydrobromide being one such compound. The current experimental setting can be employed for cell-based high-throughput screening of various compound libraries.

\section{Introduction}

Cardiomyocyte injury (necrosis and apoptosis) plays a crucial role in the pathogenesis of acute myocardial infarction during the ischemic phase. There is also a secondary myocyte injury (termed 'reperfusion injury') in conjunction with successful coronary revascularization, evidenced by a secondary elevation of plasma enzymes indicative of myocyte injury $(1,2)$. Identification of compounds that reduce reperfusionassociated myocyte death, therefore, is important, and a number of drugs that have entered clinical trials were aimed at attenuation of myocyte reperfusion injury (3-6).

The pathogenesis of reperfusion injury of the heart is complex, but it is frequently modeled in vitro using ischemic and reoxygenated perfused hearts. Here we developed an in vitro model of myocardial reperfusion injury in $\mathrm{H} 9 \mathrm{c} 2$ rat cardiomyocytes and applied a cell-based high-throughput approach to screen a standard library of pharmacologically active compounds (LOPAC) in order to identify compounds with cardioprotective effects.

As there is clear evidence that the generation of reactive oxygen and nitrogen species plays a primary role in the 
pathogenesis of myocardial reperfusion injury (7-10), cell death was induced by hydrogen peroxide treatment. In one set of screening experiments, the compounds were added in a pretreatment regimen. In a subsequent set of experiments, the time of the administration of the compounds to be screened was delayed relative to the hydrogen peroxide treatment, in order to simulate a clinically more relevant situation, and also to avoid the identification of antioxidant compounds that directly interfere with the primary effect of hydrogen peroxide in inducing cell injury. Since activation of the nuclear enzyme poly(ADP-ribose) polymerase (PARP) plays a crucial role in myocyte death during coronary ischemia-reperfusion (11-15), a potent PARP inhibitor was included in the assays as a positive control.

A number of compounds, including several dopamine D1 receptor agonists emerged from the assays as significant cytoprotective agents; the mechanism of the protective action of these compounds was therefore subsequently investigated in more detail.

\section{Materials and methods}

Generic library. A library of 1280 pharmacologically active compounds (LOPAC1280) was obtained from SigmaAldrich. The library includes drug-like molecules in the field of cell signaling and neuroscience. The compounds were dissolved at $10 \mathrm{mM}$ in dimethyl sulfoxide (DMSO) and dilutions were made either in DMSO or phosphate-buffered saline (PBS, pH 7.4) to obtain 0.5\% DMSO in the assay volume. The potent poly-ADP-ribose polymerase (PARP) inhibitor N-(-oxo-5,6-dihydro-phenanthridin-2-yl)-N,Ndimethylacetamide $\mathrm{HCl}$ (PJ34) (16) was purchased from Calbiochem. Chloro-APB (6-chloro-7,8-dihydroxy-3-allyl-1phenyl-2,3,4,5-tetrahydro-1H-3-benzazepine) hydrobromide and Bromo-APB (6-bromo-7,8-dihydroxy-3-allyl-1-phenyl2,3,4,5-tetrahydro-1H-3-benzazepine) hydrobromide were from Sigma. These compounds were dissolved in DMSO for the cell-based screen or in ultrapure water for the PARP assays.

Cell culture. $\mathrm{H} 9 \mathrm{c} 2$ rat heart myoblast cells were obtained from the European Collection of Cell Cultures and maintained in Dulbecco's modified Eagle's medium (DMEM) supplemented with $10 \%$ fetal bovine serum (Invitrogen), $4 \mathrm{mM}$ glutamine, $100 \mathrm{IU} / \mathrm{ml}$ penicillin and $100 \mu \mathrm{g} / \mathrm{ml}$ streptomycin. Seven days prior to the screening assay 10,000 cells/well were plated into 96 -well tissue culture plates and cultured at $37^{\circ} \mathrm{C}$ in a $5 \% \mathrm{CO}_{2}$ atmosphere. Cardiomyoblasts from passage numbers 40-60 were used for the screening. For the measurement of PARP activity, cells were plated into $60-\mathrm{mm}$ culture dishes and cultured until confluence.

MTT viability assay. Fresh culture medium without phenol-red was added to the cells prior to the assay, and cardiomyoblasts were challenged with 900-1100 $\mu \mathrm{M} \mathrm{H}_{2} \mathrm{O}_{2}$. In the standard assays, $30 \mathrm{~min}$ later, drugs were added at a $3-\mu \mathrm{M}$ concentration in $5 \%$ of the culture volume and cultured at $37^{\circ} \mathrm{C}$ for 3 or $24 \mathrm{~h}$. In pretreatment assays cells were pre-incubated with drugs for 30 min prior to the addition of $\mathrm{H}_{2} \mathrm{O}_{2}$ and incubated with peroxide for 3.5 or $24.5 \mathrm{~h}$. The supernatant $(30 \mu \mathrm{l})$ was saved for the measurement of the lactate dehydrogenase (LDH) release and stored at $-20^{\circ} \mathrm{C}$ until assayed. To estimate the number of viable cells 3-(4,5-dimethyl-2-thiazolyl)-2,5diphenyl-2H-tetrazolium bromide (MTT) was added to the cells at a final concentration of $0.5 \mathrm{mg} / \mathrm{ml}$ and cultured at $37^{\circ} \mathrm{C}$ for $1 \mathrm{~h}(16,17)$. Cells were washed with PBS, and the formazan dye was dissolved in isopropanol. The amount of converted formazan dye was measured at $570 \mathrm{~nm}$ with background measurement at $690 \mathrm{~nm}$ on a Powerwave reader (Biotek). A calibration curve was created by measuring the MTT converting capacity of serial dilutions of H9c2 cells, and the viable cell count was calculated using Gen5 data reduction software.

LDH assay. Cell culture supernatant $(30 \mu \mathrm{l})$ was mixed with $100 \mu \mathrm{l}$ freshly prepared LDH assay reagent to reach final concentrations of $85 \mathrm{mM}$ lactic acid, $1040 \mathrm{mM}$ nicotinamide adenine dinucleotide (NAD), $224 \mathrm{mM} \mathrm{N}$-methylphenazonium methyl sulfate (PMS), $528 \mathrm{mM}$ 2-(4-Iodophenyl)-3(4-nitrophenyl)-5-phenyl-2H-tetrazolium chloride (INT) and $200 \mathrm{mM}$ Tris ( $\mathrm{pH}$ 8.2). The changes in absorbance were either read kinetically at $492 \mathrm{~nm}$ for $15 \mathrm{~min}$ (kinetic LDH assay) or plates were incubated for $15 \mathrm{~min}$ and read at $492 \mathrm{~nm}$ with background measurement at $690 \mathrm{~nm}$ (endpoint assay) on a monochromator based reader (Powerwave HT, Biotek). LDH activity was expressed as percent values of $\mathrm{V}_{\max }$ (for kinetic assay) or $\triangle \mathrm{OD}$ (492-690 for endpoint assay) of control wells receiving hydrogen peroxide $(100 \%)$, with controls receiving vehicle only as blank $(0 \%)$.

Measurement of PARP activity by PAR Western blot analysis. Confluent cultures of $\mathrm{H} 9 \mathrm{c} 2$ cells in $60-\mathrm{mm}$ dishes were washed with serum-free medium and pretreated with drugs or vehicle for $30 \mathrm{~min}$, and then cells were challenged with $500 \mu \mathrm{M} \mathrm{H}_{2} \mathrm{O}_{2}$ (Sigma) for $60 \mathrm{~min}$. After three washes with ice-cold phosphate-buffered saline (PBS, pH 7.4), cells were lysed in $400 \mu 1$ denaturing loading buffer (20 mM Tris, $2 \%$ SDS, $10 \%$ glycerol, $6 \mathrm{M}$ urea, $100 \mu \mathrm{g} / \mathrm{ml}$ bromophenol blue, $200 \mathrm{mM}$ B-mercaptoethanol), sonicated and boiled. Lysates $(10 \mu 1)$ were resolved on $4-12 \%$ NuPage Bis-Tris acrylamide gels (Novex, Invitrogen) and transferred to nitrocellulose. Membranes were blocked in $10 \%$ non-fat dried milk and probed overnight with anti-poly(ADP-ribose) antibody (antiPAR, 1:2000, Calbiochem). Anti-rabbit-horseradish peroxidase conjugate (HRP, 1:2000, Cell Signaling) and enhanced chemiluminescent substrate (ECL, Pierce) were used to detect the chemiluminescent signal in a CCD-camerabased chemiluminescence detection system (Genegnome HR, Syngene). To normalize signals, membranes were re-probed with an antibody against $\alpha$-tubulin. Briefly, membranes were stripped in $62.5 \mathrm{mM}$ Tris, $2 \%$ SDS, $100 \mathrm{mM}$ ß-mercaptoethanol at $60^{\circ} \mathrm{C}$ for $30 \mathrm{~min}$, blocked overnight in $5 \%$ non-fat dried milk and re-probed with anti-tubulin (1:6000, Sigma) monoclonal antibody. After the application of anti-mouseHRP conjugate (1:10 000, Cell Signaling) and ECL, chemiluminescence was detected with the same imaging system. The PAR signal at $116 \mathrm{kDa}$, which corresponds to the automodified form of PARP-1, and the chemiluminescent signal at $\sim 50 \mathrm{kDa}$ for tubulin were quantitated with Genetools analysis software, and their ratio was expressed as relative PARP activity. 
a

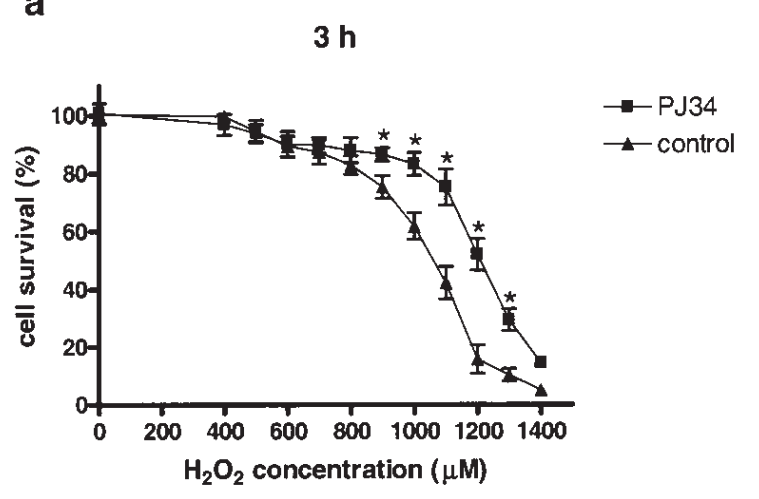

b

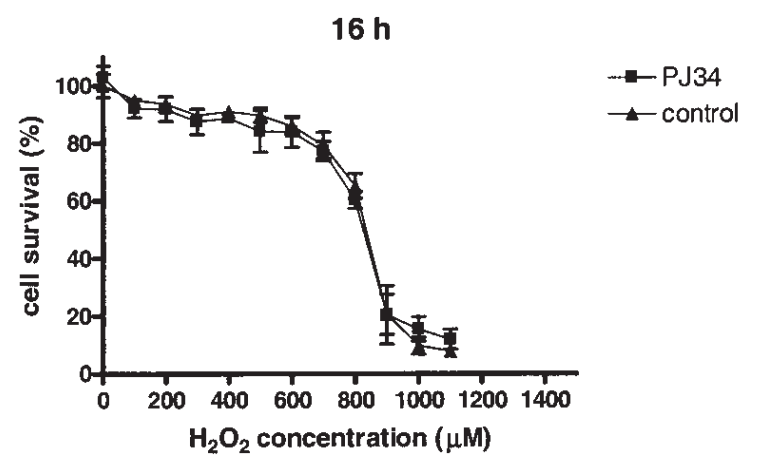

c

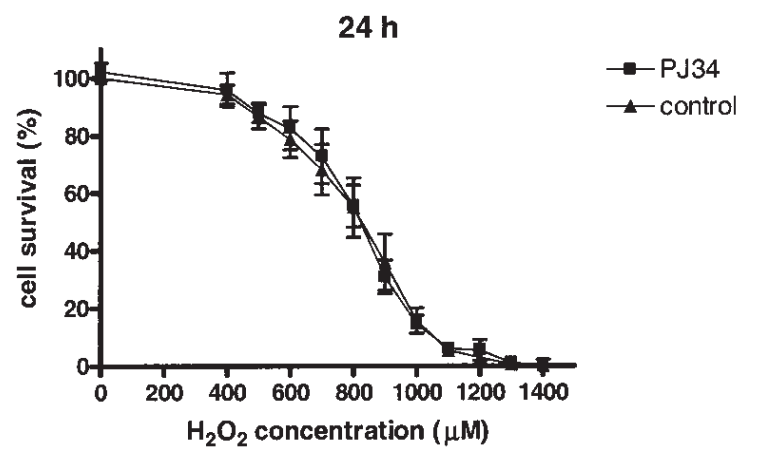

Figure $1 . \mathrm{H}_{2} \mathrm{O}_{2}$-induced cytotoxicity in the absence or presence of the PARP inhibitor PJ34. Percent survival values at 3 (a), 16 (b) and 24 h (c) are shown as the mean \pm SEM. Controls received increasing concentrations of $\mathrm{H}_{2} \mathrm{O}_{2}$, and PJ34-treated cells received PJ34 at a $3-\mu \mathrm{M}$ final concentration, $30 \mathrm{~min}$ after the $\mathrm{H}_{2} \mathrm{O}_{2}$ treatment. Data are shown as the mean $\pm \mathrm{SEM}\left({ }^{*} \mathrm{p}<0.05\right)$.

Cell-free colorimetric PARP activity assay. PARP activity was measured with a commercial PARP assay kit according to the protocol provided by the manufacturer (R\&D Systems) (16). Briefly, test compounds and 1 U PARP enzyme were added to histone-coated wells. A cocktail containing activated DNA and biotinylated-NAD was added to the wells and incubated for $60 \mathrm{~min}$. After 4 washes with PBS biotinylatedribose, residues were detected with streptavidine-HRP conjugate and TACS-sapphire substrate. After $30 \mathrm{~min}$ the reaction was stopped with $0.2 \mathrm{M} \mathrm{HCl}$, and absorbance values were measured at $450 \mathrm{~nm}$.

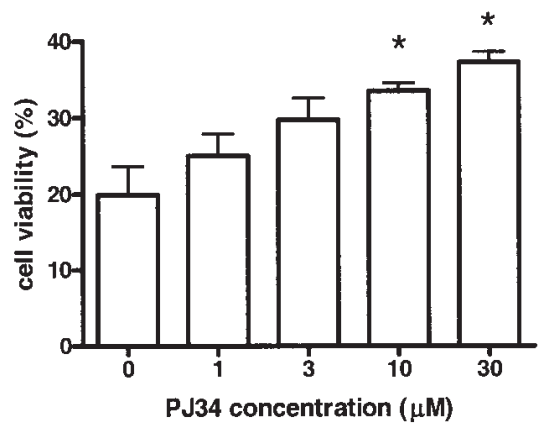

Figure 2. PARP inhibitor induced cytoprotection. H9c2 cardiomyoblasts were treated with $\mathrm{H}_{2} \mathrm{O}_{2}(850 \mu \mathrm{M})$ and various concentrations of PJ34. Cell viability was quantitated with MTT assay after $24 \mathrm{~h}$. Viable cell counts are expressed as percent values of vehicle-treated cells. Data are shown as the mean $\pm \operatorname{SEM}\left({ }^{*} \mathrm{p}<0.05\right)$.

\section{Results and discussion}

Establishment of the oxidant-induced cardiac cell death model. We aimed to achieve a reproducible myocyte cell death model, which can be used in cell-based screening for compounds that exhibit cytoprotective effects. The H9c2 rat cardiomyoblast cell line was chosen to provide a source of cells with a well-characterized phenotype. Cells were cultured for 7 days prior to the assay to reach a more differentiated state similar to mature cardiomyocytes. When cells were treated with increasing concentrations of $\mathrm{H}_{2} \mathrm{O}_{2}$ for $3 \mathrm{~h}$, a dosedependent reduction was detected in cell viability (Fig. 1a) using the MTT assay. The reduction in viable cell count was $>25 \%$ for up to a $900-\mu \mathrm{M}$ final concentration of $\mathrm{H}_{2} \mathrm{O}_{2}$. When elevating the concentration of hydrogen peroxide by an additional $300-\mu \mathrm{M}$ range (to reach a $1.2-\mathrm{mM}$ concentration), the viable cell count rapidly decreased to near zero. The sensitivity of the cells to the toxic effect of $\mathrm{H}_{2} \mathrm{O}_{2}$ decreased with the number of initial cell count and passage number (data not shown). Pretreatment with the potent poly(ADPribose)-polymerase (PARP) inhibitor PJ34 $(3 \mu \mathrm{M})$ for $30 \mathrm{~min}$ significantly increased the number of viable cells at concentrations that caused $>20 \%$ reduction in cell viability. The results were similar when $\mathrm{PJ} 34$ was added $30 \mathrm{~min}$ after the $\mathrm{H}_{2} \mathrm{O}_{2}$ treatment and cell viability was quantitated $3 \mathrm{~h}$ after the addition of the PARP inhibitor; $70 \%$ cell viability was measured for the PJ34-treated cells at peroxide concentrations that caused $60 \%$ reduction in the vehicle-treated group. When the incubation time was increased to 16 or $24 \mathrm{~h}$, the tolerated $\mathrm{H}_{2} \mathrm{O}_{2}$ concentration decreased to $<700 \mu \mathrm{M}$ and the protective effect of PJ34 $(3 \mu \mathrm{M})$ observed at $3 \mathrm{~h}$ was completely abolished (Fig. 1b and c). However, PJ34 resulted in a significant increase in viability at $24 \mathrm{~h}$ when applied at higher concentrations (Fig. 2).

Based on the above findings, cells were treated with hydrogen peroxide to attain $\sim 50 \%$ cell death after $3 \mathrm{~h}$ (shortterm survival) or $24 \mathrm{~h}$ (long-term survival) of incubation. Test compounds were added either $30 \mathrm{~min}$ prior to or $30 \mathrm{~min}$ after the application of hydrogen peroxide (Fig. 3). All our assay plates included negative controls that remained untreated (CTL3), positive controls that were treated with peroxide only (CTL1) and hydrogen peroxide-treated cells which also 


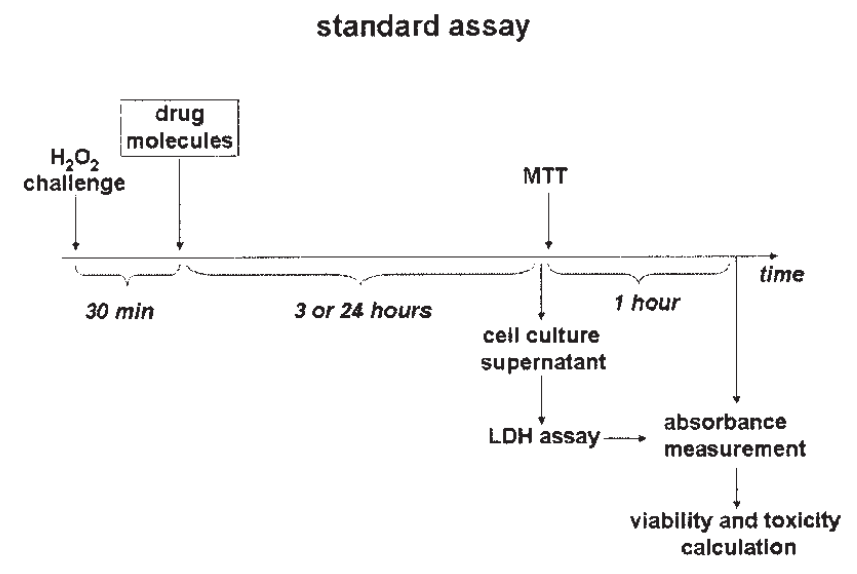

pretreatment assay

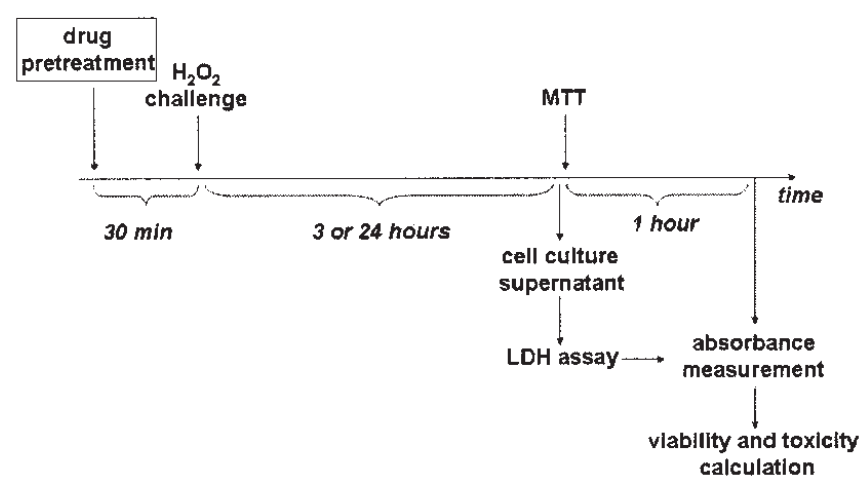

Figure 3. Experimental design. In standard assays treatment with the test compounds followed $\mathrm{H}_{2} \mathrm{O}_{2}$ challenge by 30 min, whereas in the pretreatment assays cells received test compound treatment $30 \mathrm{~min}$ prior to the peroxide challenge. Incubation periods of 3 and $34 \mathrm{~h}$ were applied in both assay types, followed by the MTT viability assay, which lasted for $1 \mathrm{~h}$.

received the PARP inhibitor PJ34 as a pharmacological positive control (CTL2). The relatively narrow range of $\mathrm{H}_{2} \mathrm{O}_{2}$ that caused $50 \%$ reduction in cell viability and the variability of cell counts observed 7 days after plating at different passage numbers often resulted in variable cell survival data ranging from nearly complete cell death to insignificant reduction in viability at a given peroxide concentration. To make the measurements taken on separate plates comparable, we applied a normalization of the viability data, which presumed a $40 \%$ normalized cell survival in the peroxide treated controls and a $100 \%$ survival for untreated controls by using the following equation:

Normalized viability $=\frac{60}{100-\text { mean (CTL1) }} \times$ Measured viability $+100 \times\left(1-\frac{60}{100-\text { mean (CTL1) }}\right)$

The feasibility of linear transformation of viability data was supported by the reproducibility of normalized viability values received for PARP inhibitor-treated controls over a wide range of viability values. Mean viability increase values for the PJ34-treated controls from 100 randomly selected plates were plotted over the measured mean viability values of peroxide-treated controls (Fig. 4). Fig. 4c shows that using
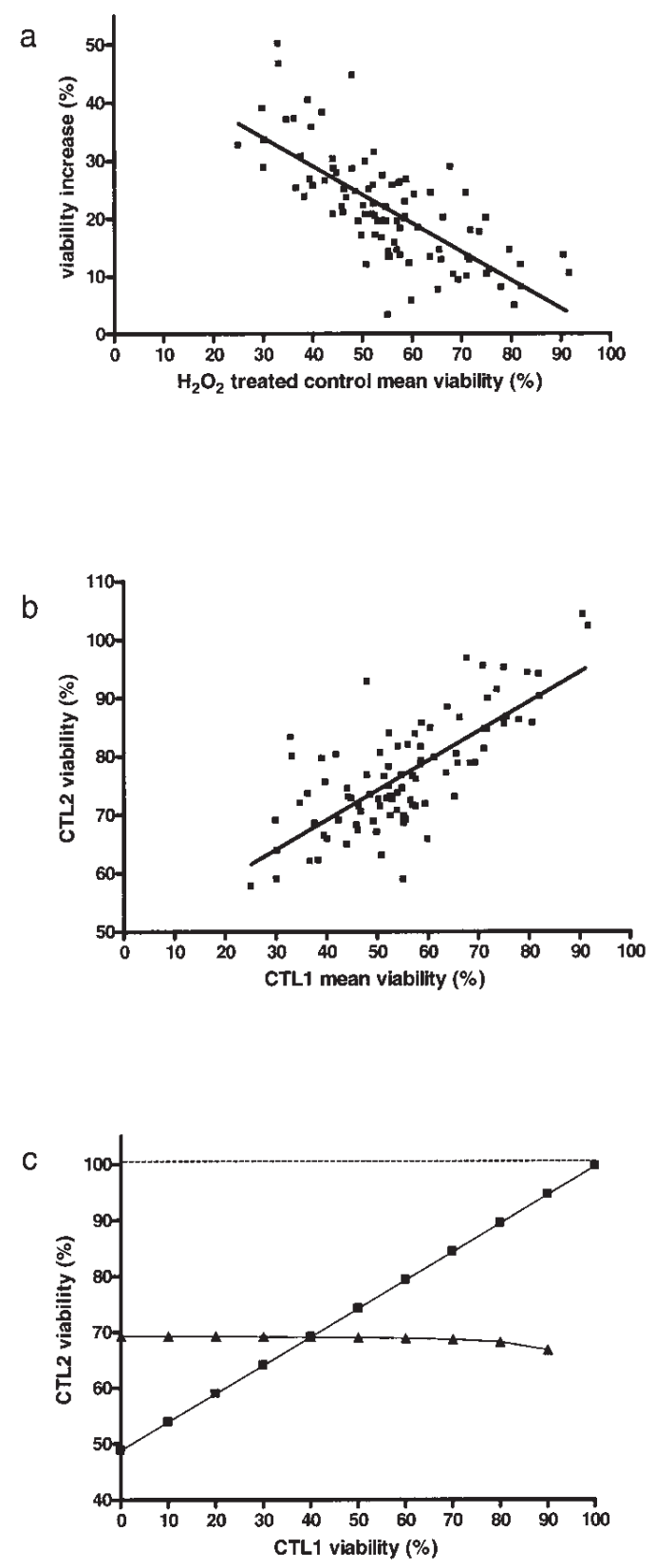

Figure 4. PARP inhibitor-induced cytoprotection at various degrees of oxidant-induced cell death. PJ34-induced mean viability increase (a) and absolute viability (b) values are shown at various degrees of $\mathrm{H}_{2} \mathrm{O}_{2}$-induced cell survival (CTL1 viability) from 100 independent experiments. Data are shown as percent values of the vehicle-treated controls. The linear correlation graph (a) equation was used to normalize $\mathrm{H}_{2} \mathrm{O}_{2}$ and PJ34-treated cell (CTL2) viability data. Expected (ロ) and normalized (A) viability data are shown (c); the $\mathrm{x}$-axis represents CTL1 percent viability.

this equation to predict viability data of the PJ34-treated controls resulted in $<1 \%$ variability in the normalized values for the range of $10-70 \%$ measured cell survival of the peroxide-treated controls.

PARP activation plays a central role in oxidative stressinduced cardiomyocyte death. PARP inhibition by PJ34 dose-dependently increased the number of viable cells in the $\mathrm{H}_{2} \mathrm{O}_{2}$-induced cell death model (Fig. 2). To further clarify the role of PARP activation in this model, confluent $\mathrm{H} 9 \mathrm{c} 2$ cultures 


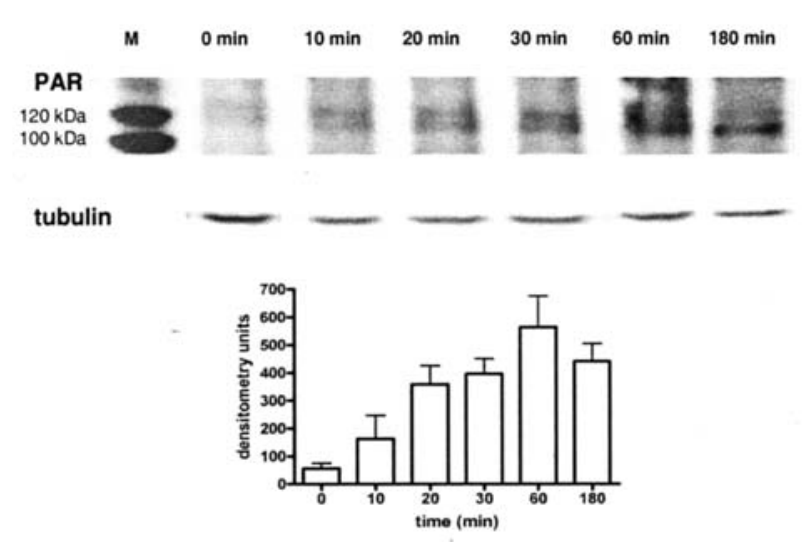

b
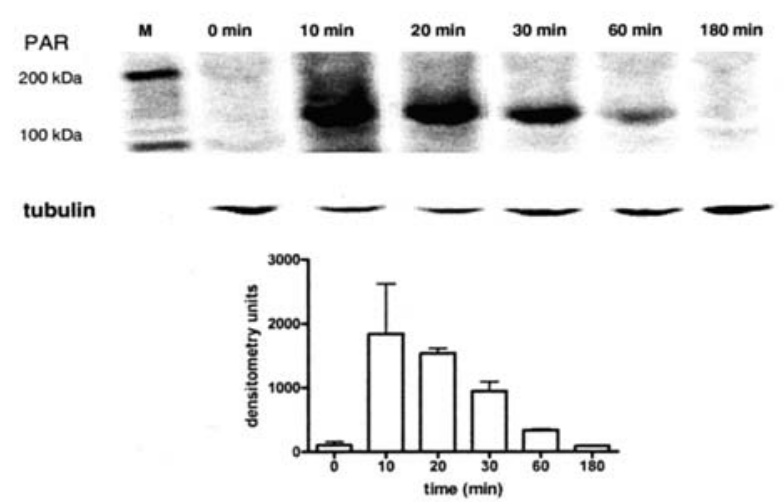

c

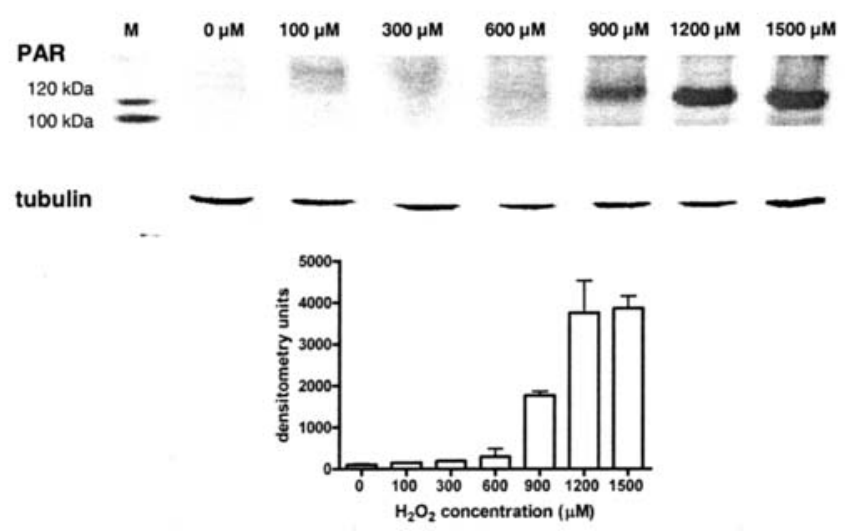

Figure 5. PARP activation in response to $\mathrm{H}_{2} \mathrm{O}_{2}$ treatment. $\mathrm{H} 9 \mathrm{c} 2$ cells were treated with $500 \mu \mathrm{M}$ (a) and $1 \mathrm{mM}$ (b) $\mathrm{H}_{2} \mathrm{O}_{2}$ for various time points or with various concentrations of $\mathrm{H}_{2} \mathrm{O}_{2}$ for $60 \mathrm{~min}$ (c). PARP activation was detected as poly(ADP-ribose) polymer (PAR) formation on the Western blots. Representative blots and densitometric analysis results are shown. The $120-\mathrm{kDa}$ band corresponding to PARP automodification was analysed by densitometry. PAR densitometry results were normalized to tubulin signal, and are shown as the mean \pm SEM $\left({ }^{*} \mathrm{p}<0.05\right)$.

were treated with $500 \mu \mathrm{M}$ or $1000 \mu \mathrm{M} \mathrm{H}_{2} \mathrm{O}_{2}$ for various lengths of time, and Western blotting was performed on total cell lysates for poly(ADP-ribose) (PAR), the product of PARP enzyme activity. PARP activation was detected 5 min after

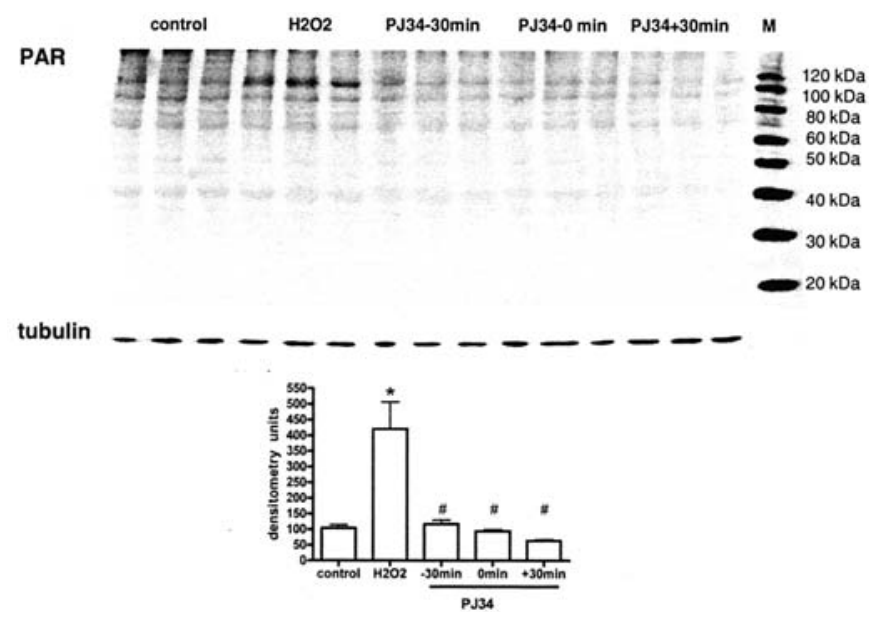

Figure 6. PJ34 blocks PAR polymer formation. PARP was activated in H9c2 cells by treating cells with $\mathrm{H}_{2} \mathrm{O}_{2}(500 \mu \mathrm{M})$ for $60 \mathrm{~min}\left(\mathrm{H}_{2} \mathrm{O}_{2}\right)$. Cells received $3 \mu \mathrm{M}$ PJ34 30 min prior to (PJ34 - $30 \mathrm{~min}$ ), simultaneously with (PJ34 - 0 min) or $30 \mathrm{~min}$ after $(\mathrm{PJ} 34+30 \mathrm{~min})$ the $\mathrm{H}_{2} \mathrm{O}_{2}$ challenge. PARP activation was detected by Western blotting. A representative blot and densitometric analysis results are shown. ${ }^{*} \mathrm{p}<0.05$ compared to the control, ${ }^{\#} \mathrm{p}<0.05$ compared to $\mathrm{H}_{2} \mathrm{O}_{2}$-treated cells.

the addition of $\mathrm{H}_{2} \mathrm{O}_{2}$ in both cases, but showed different kinetics. Maximum activity was reached only after $60 \mathrm{~min}$ when $500 \mu \mathrm{M} \mathrm{H}_{2} \mathrm{O}_{2}$ was used and the PAR signal remained unaltered for the third hour of incubation. $\mathrm{H}_{2} \mathrm{O}_{2}(1000 \mu \mathrm{M})$ resulted in a more robust activation, and the signal reached maximum values in 20 min followed by a decline to near baseline values at $3 \mathrm{~h}$ (Fig. $5 \mathrm{a}$ and b).

$\mathrm{H} 9 \mathrm{c} 2$ cells were also challenged with increasing concentrations of $\mathrm{H}_{2} \mathrm{O}_{2}$ for $1 \mathrm{~h}$ to directly compare the PARP activation signal. A significant degree of PARP activation was detected from $\mathrm{H}_{2} \mathrm{O}_{2}$ concentrations $>300 \mu \mathrm{M}$, with the highest values measured at $>1 \mathrm{mM}$ peroxide (Fig. 5c). PJ34 abolished PARP activation when $500 \mu \mathrm{M} \mathrm{H}_{2} \mathrm{O}_{2}$ was used to activate PARP, irrespective of whether it was applied $30 \mathrm{~min}$ earlier, simultaneously with the oxidant or 30 min later (Fig. 6). PJ34 also significantly reduced PARP activation when $1 \mathrm{mM}$ $\mathrm{H}_{2} \mathrm{O}_{2}$ was applied (data not shown).

Results from the generic library screening. In the $\mathrm{H}_{2} \mathrm{O}_{2}-$ induced cell death model, we used 4 different assay designs to identify compounds with cytoprotective potential; 3- and 24-h incubation periods were applied and test compounds were added either $30 \mathrm{~min}$ prior to or $30 \mathrm{~min}$ after the hydrogen peroxide challenge (Fig. 3). The following two criteria were used to identify drugs that reproducibly result in cytoprotection: i) normalized viability data were averaged for replicate plates and drugs that resulted in greater mean viability values than the average $\pm 2 \mathrm{SD}$ of all $\mathrm{H}_{2} \mathrm{O}_{2}$-treated wells, except that the PARP inhibition controls were selected as hits; ii) molecules were also selected, if the difference between the mean and the standard deviation (SD) of the normalized viability values was greater than the sum of the average viability and its standard deviation for all $\mathrm{H}_{2} \mathrm{O}_{2}$-treated sample wells (see example in Fig. 7).

Table I summarizes the hit molecules in the 3- and 24-h assays. Known PARP inhibitor compounds, with previously 


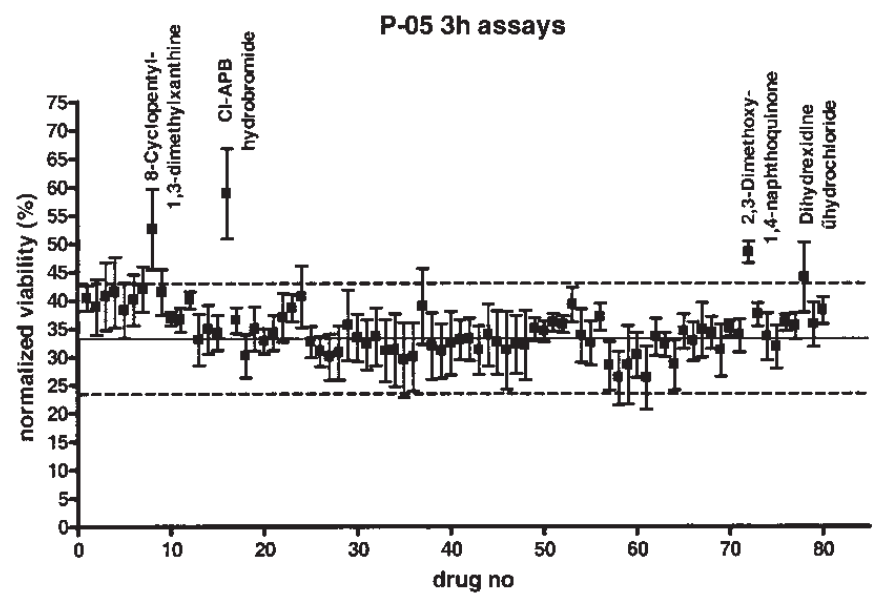

Figure 7. A representative example (normalized viability values for a series of test compounds) demonstrating the identification of Cl-APB hydrobromide as a cytoprotective compound. Cell viability values were transformed to obtain $40 \%$ viability for the average of all samples and $\mathrm{H}_{2} \mathrm{O}_{2}$-treated controls and $100 \%$ cell viability in vehicle-treated wells. The transformed viability values measured in independent experiments were averaged for each sample. Mean \pm SEM values are shown. Continuous line represents the mean of all samples, while the dashed line represents the \pm 2 SD interval.

documented cardioprotective effects (13) have reproducibly emerged as effective molecules at $3 \mathrm{~h}$. These compounds also showed a trend for cytoprotection at $24 \mathrm{~h}$ but these effects remained under the level our selection criteria; this is consistent with the results obtained with the positive control PARP inhibitor PJ34, which also lost some of its cytoprotective potency by $24 \mathrm{~h}$. Other active molecules emerging from the screen included drugs that interfere with DNA repair and cell cycle progression. Their protective effect is likely based on a general mechanism independent of cell type. Furthermore, active molecules found in our 3-h assay included ion channel blockers and cell surface receptors that were previously shown to ameliorate cell injury in oxidative stress in cultured cells (in many cases cardiomyocytes) in vitro or in various models of myocardial infarction and injury in vivo $(4,6,17-28)$. The effects of some of these compounds can be, again, linked to the PARP pathway, as minocycline has recently been identified as a fairly potent competitive PARP inhibitor $(19,20)$, and the protective effect of certain calcium modulators may also be linked to an early calcium-dependent step in the cellular activation of PARP (18). The cytoprotective effect of nicotine has also been demonstrated previously, and occurs, in part via inhibition of the release of the nuclear protein high mobility group protein B-1 (21). The cardioprotective effect of dipyridamole, chlorpromazine, hydrocorticosterone, forskolin and A1 agonists emerged from our screening as well: cytoprotective and/or cardioprotective effects of these compounds have also previously been described in the literature, not uncommonly with a somewhat unspecific or mixed mechanism of action (e.g. glucocorticoids are known as 'membrane stabilizing' agents). Interestingly, cholinergic agonists also showed some protective effect in $3 \mathrm{~h}$, which may be the consequence of the mixed cardiomyocyte and skeletal muscle phenotype of the H9c2 cells. Overall, the identification of active molecules that act on various cell surface receptors establishes our
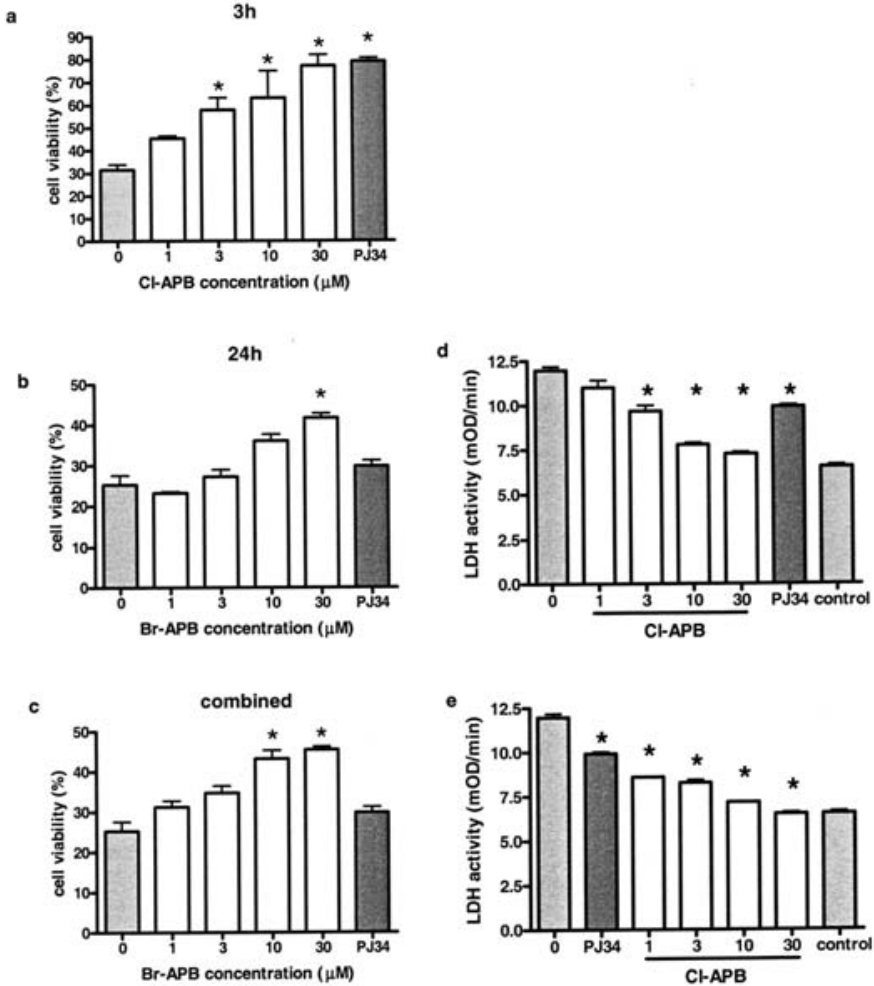

Figure 8. Cytoprotective effect of APB hydrobromide molecules. H9c2 cardiomyocytes were treated with $\mathrm{H}_{2} \mathrm{O}_{2}$ for 3 (a) or $24 \mathrm{~h}$ (b-e). Thirty minutes after the $\mathrm{H}_{2} \mathrm{O}_{2}$ challenge $(1100 \mu \mathrm{M}), \mathrm{Cl}$-APB hydrobromide (a,d,e) or Br-APB hydrobromide $(b, c)$ was added to the cells at the indicated concentrations. The PJ34 group received $3 \mu \mathrm{M}$ PJ34; the controls were treated with vehicle only. In the combined treatment $(\mathrm{c}, \mathrm{e})$ each sample received PJ34, except for controls. Cell viability was measured by MTT assay and expressed as percent values of controls. LDH activity in cell culture supernatant was measured kinetically and is shown in $\mathrm{mOD} / \mathrm{min}$. Mean \pm SEM values are shown. ${ }^{*} \mathrm{p}<0.05$ compared to $\mathrm{H}_{2} \mathrm{O}_{2}$-treated cells

model as a valid tool to discover novel cytoprotective drugs in a model of myocyte necrosis. Because of the experimental design employed in our standard assays (delayed treatment of the test compounds, relative to the administration of hydrogen peroxide), we did not seek to identify compounds that directly interfered with the primary oxidant injury induced by hydrogen peroxide. It is noteworthy, nevertheless, that in cultured cells and hearts exposed to a single burst of prooxidant challenge, a secondary, mitochondria-derived release of oxidant species also occurs $(29,30)$. Hence, it is conceivable that some of the compounds identified herein may have attenuated this secondary oxidant response.

Most of the drugs that provided cytoprotection in $3 \mathrm{~h}$ were less protective in the $24-\mathrm{h}$ assays. However, the cytoprotection afforded by hydrocorticosterone and forskolin was sustained in the long term. Chloro-APB hydrobromide, a D1 dopamine receptor agonist, and some closely related molecules (Bromo-APB- and Chloro-PB hydrobromide) resulted in superior cell survival values at $24 \mathrm{~h}$ and drastically different effects compared to other D1 dopamine receptor agonists that showed a protective effect in $3 \mathrm{~h}$. As cardioprotective effects of D1 ligands have not been previously described in the literature, and yet these compounds afforded a significant degree of sustained cytoprotection in all of our assays, these compounds were selected for further study. 
Table I. Cytoprotective drugs identified in rat cardiac myocytes exposed to cytotoxic concentrations of hydrogen peroxide. ${ }^{\mathrm{a}}$

\begin{tabular}{lll}
\hline Name & Action & Mean viability increase (\%) \\
\cline { 2 - 3 } & ST & $3 \mathrm{~h}$ \\
PRE & ST
\end{tabular}

Cell cycle: DNA repair and DNA synthesis inhibitors, cyclin-dependent protein kinase inhibitors

4-Amino-1,8-naphthalimide

1,5-Isoquinolinediol

PARP inhibition

20

Benzamide

25
12

$12-12$

m-Iodobenzylguanidine hemisulfate

$6(5 \mathrm{H})$-Phenanthridinone

1,10-Phenanthroline monohydrate

Amsacrine hydrochloride

Topoisomerase II inhibition

Ellipticine

Nucleotide synthesis inhibition

Mizoribine

DNA synthesis inhibition

Mitoxantrone

Pyrimidine synthesis inhibition

Leflunomide

Cyclin-dependent kinase inhibition

Kenpaullone

Olomoucine

Actinonin

Induces cell cycle arrest

4-Hydroxybenzhydrazide

Chelates to DNA, blocks peroxidase

Indirect PARP inhibitors (?): dopaminergic and adenosinergic drugs

( \pm )-6-Chloro-PB hydrobromide

$( \pm)$-Chloro-APB hydrobromide

$\mathrm{R}(+)$-6-Bromo-APB hydrobromide

( \pm )-SKF 38393, N-allyl-, hydrobromide

Dihydrexidine hydrochloride

Fenoldopam bromide

SKF 75670 hydrobromide

SKF 83565 hydrobromide

SKF 83959 hydrobromide

SKF 89626

S-(-)-Lisuride

Chlorprothixene hydrochloride

S-(-)-Eticlopride hydrochloride

(+)-Butaclamol hydrochloride

(-)-Quinpirole hydrochloride

BP 897

U-99194A maleate

PD 168,077 maleate

Apomorphine hydrochloride hemihydrate

Dihydroergocristine methanesulfonate

Mesulergine hydrochloride

Chlorpromazine hydrochloride

8-Cyclopentyl-1,3-dimethylxanthine

(S)-ENBA

Dipyridamole
D1 dopamine receptor agonist (also acts as $\quad 16$ an indirect PARP inhibitor; see Results)

D2 Dopamine receptor agonist

D2 dopamine receptor antagonist

Dopamine receptor antagonist

D2/D3 receptor agonist

D3 dopamine receptor agonist

D3 dopamine receptor antagonist

D4 dopamine receptor agonist

Non-selective dopamine receptor agonist

Dopamine receptor agonist, serotonin receptor antagonist

Dopamine receptor antagonist

Adenosine A1 receptor antagonist

Adenosine A1 receptor agonist

Adenosine transport inhibitor

$$
8
$$

16

16

$\begin{array}{ll}6 & 6 \\ 6 & 4\end{array}$


Table I. Continued.

\begin{tabular}{|c|c|c|c|c|}
\hline \multirow[t]{3}{*}{ Name } & \multirow[t]{3}{*}{ Action } & \multicolumn{3}{|c|}{ Mean viability increase $(\%)$} \\
\hline & & \multicolumn{2}{|c|}{$3 \mathrm{~h}$} & $24 \mathrm{~h}$ \\
\hline & & ST & PRE & PRE \\
\hline
\end{tabular}

Anti-inflammatory drugs, antioxidants

Hydrocortisone

Steroids 11

Hydrocortisone 21-hemisuccinate sodium

Beclomethasone

Betamethasone

Corticosterone

COX-inhibitors

Ketorolac tris salt 4

Meclofenamic acid sodium

$\mathrm{N}$-(4-acetamidophenyl)indomethacinamide

AA-861

5-lipoxygenase inhibitor

7

Caffeic acid phenethyl ester

$\mathrm{NF \kappa B}$ inhibitor

Membrane protease inhibitor,

Minocycline hydrochloride inhibits cell proliferation

Luteolin

Antioxidant and radical scavenger

10

( \pm )- $\alpha$-Lipoic Acid

Coenzyme pyruvate dehydrogenase

2,3-Dimethoxy-1,4-naphthoquinone

Redox cycling agent

12

5

Anticancer agent, apoptosis inducer

Aminoguanidine hemisulfate

NOS inhibitor

Sphingolipid signaling inhibitor

Muscle relaxation, cholinergic drugs

Vincristine sulfate

Microtubule assembly inhibitor

14

ML-7

(-)-Eseroline fumarate

Myosin light chain kinase inhibitor

(-)-Scopolamine hydrobromide

(-)-Scopolamine methyl nitrate

Cholinesterase inhibitor

Muscarinic acetylcholine receptor

(-)-Nicotine hydrogen tartrate salt

1,1-Dimethyl-4-phenyl-piperazinium iodide

Nicotinic acetylcholine receptor agonist

$\begin{array}{lll}12 & 3 & 7\end{array}$

Carbachol

Acetylcholine receptor agonist

Carisoprodol

Skeletal muscle relaxant

CB34

Peripheral benzodiazepine receptor agonist

21

Oxiracetam

Nootropic agent, muscle relaxation (?)

Centrophenoxine hydrochloride

Cholinergic action (?)

Adrenergic drugs, imidazoline receptor interfering agents

Phenoxybenzamine hydrochloride

$\alpha 1$ adrenoceptor antagonists

Moxisylyte hydrochloride

Yohimbine hydrochloride

$\alpha 2$ adrenoceptor blockers

Imiloxan hydrochloride

Pindolol

$\beta$ adrenoceptor blocker 
Table I. Continued.

\begin{tabular}{lcc}
\hline Name & Action & $\frac{\text { Mean viability increase (\%) }}{3 \mathrm{~h}}$ \\
\hline ST & PRE $\overline{\text { ST }}$ PRE
\end{tabular}

Adrenergic drugs, imidazoline receptor interfering agents (continued)

3,5-Dinitrocatechol

Quinacrine dihydrochloride

Idazoxan hydrochloride

BU224 hydrochloride

Ion channel blockers

Nicardipine hydrochloride

Nitrendipine

Cinnarizine

Diltiazem hydrochloride

Benzamil hydrochloride

Ouabain

2,3-Butanedione monoxime

Amiloride hydrochloride

cAMP/PKA activation

Forskolin

8-Methoxymethyl-3-isobutyl-1-methylxanthine

T-0156
COMT inhibitor

MAO inhibitor

Imidazoline I2 agonist/I1 antagonist,

$\alpha$ adrenoceptor antagonist

Imidazoline $\mathrm{I} 2$ antagonist

11

14

6

16

Calcium channel blockers $\quad 8$

$21 \quad 25$

$6 \quad 18$

Blocker of $\mathrm{Na}^{+} / \mathrm{H}^{+}$and $\mathrm{Na}^{+} / \mathrm{Ca}^{2+}$ channels

$\mathrm{Na}^{+}-\mathrm{K}^{+}$ATPases blocker

4

ATP-sensitive $\mathrm{K}^{+}$channel blocker

14

5

$\mathrm{Na}^{+}$channel blocker

10
Ro 20-1724

$\mathrm{T}-1032$

H-9 dihydrochloride

Sp-cAMPS triethylamine

Rp-cAMPS triethylamine

Adenylate cyclase activator

6

$12 \quad 10$

H-8 dihydrochloride
Phosphodiesterase inhibitors

Phosphodiesterase inhibitors

14
6

22

Inhibitors of cAMP-dependent protein kinase

12

Phosphorylation inhibitors, tyrosine kinase inhibitors

Tyrphostin AG 528

U0126

Rottlerin

Piceatannol

Tyrphostin AG 112

Tyrphostin AG 835
Tyrosine kinase inhibitor

18

MEK inhibi

PKC and CaM kinase III inhibitor

Non-receptor kinase Syk and Lck inhibitor

Protein tyrosine kinase inhibitor 
Table I. Continued.

\begin{tabular}{|c|c|c|c|c|}
\hline \multirow[t]{3}{*}{ Name } & \multirow[t]{3}{*}{ Action } & \multicolumn{3}{|c|}{ Mean viability increase $(\%)$} \\
\hline & & \multicolumn{2}{|c|}{$3 \mathrm{~h}$} & $24 \mathrm{~h}$ \\
\hline & & ST & PRE & PRE \\
\hline
\end{tabular}

GABAergic drugs, anticonvulsive drugs

(+)-Bicuculline

Isoguvacine hydrochloride

(土)-Baclofen

CGP-7930

NCS-356

N-(4-Amino-2-chlorophenyl)phthalimide Valproic acid sodium
GABA-A receptor antagonist $\quad 10$

GABA-A receptor agonist 10

GABA-B agonist, muscle relaxant 5

GABA-B modulator 7

GABA agonist

Anticonvulsive drugs
Serotoninergic drugs

N,N-Dipropyl-5-carboxamidotryptamine maleate

5-HT1A serotonin receptor agonist

7

5-HT1 serotonin receptor antagonist

6

Methiothepin mesylate

SB 204070 hydrochloride

Fluoxetine hydrochloride

5-HT4 serotonin receptor antagonist

Selective serotonin reuptake inhibitor

6

7

Histaminergic drugs

Ketotifen fumarate

Terfenadine

H1 Histamine receptor antagonist

18

H3 Histamine receptor antagonist methyl ether hydrochloride

4-Imidazolemethanol hydrochloride

Histonol dehydrogenase inhibitor

17

NMDA glutamate receptor interfering agents

Pentamidine isethionate

NMDA glutamate receptor antagonist

33

Spermidine trihydrochloride

NMDA modulator

6

DL-threo-ß3-hydroxyaspartic acid

Glutamate transport inhibitor

12

Potentiates NMDA signaling

23

Purinergic

$\alpha, \beta$-Methylene adenosine 5'-triphosphate dilithium

$\mathrm{P} 2$ receptor agonist

9

NF 023

$\mathrm{P} 2 \mathrm{X} 1$ receptor antagonist

5

Others: tachykinin and capsaicin analogues

WIN 62,577

NK1 tachykinin receptor antagonist

Capsazepine

Vanilloid receptor antagonists

7

$\mathrm{N}$-Vanillylnonanamide

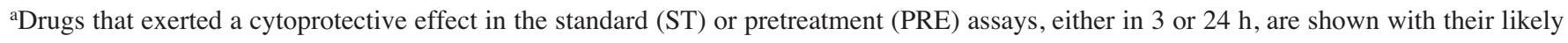
mode of action. In case of cytoprotective action, normalized mean increases in viability are shown as percent values.

Chloro-APB and Bromo-APB hydrobromide are potent cytoprotective compounds. Treating the cells with chloro-APB hydrobromide 30 min after the $\mathrm{H}_{2} \mathrm{O}_{2}$ challenge that resulted in
$70 \%$ cell death dose-dependently increased cell survival at $3 \mathrm{~h}$. Survival exceeded $70 \%$ in the case of $30 \mu \mathrm{M}$ chloro-APB hydrobromide (Fig. 8a). The level of cell survival seen with 

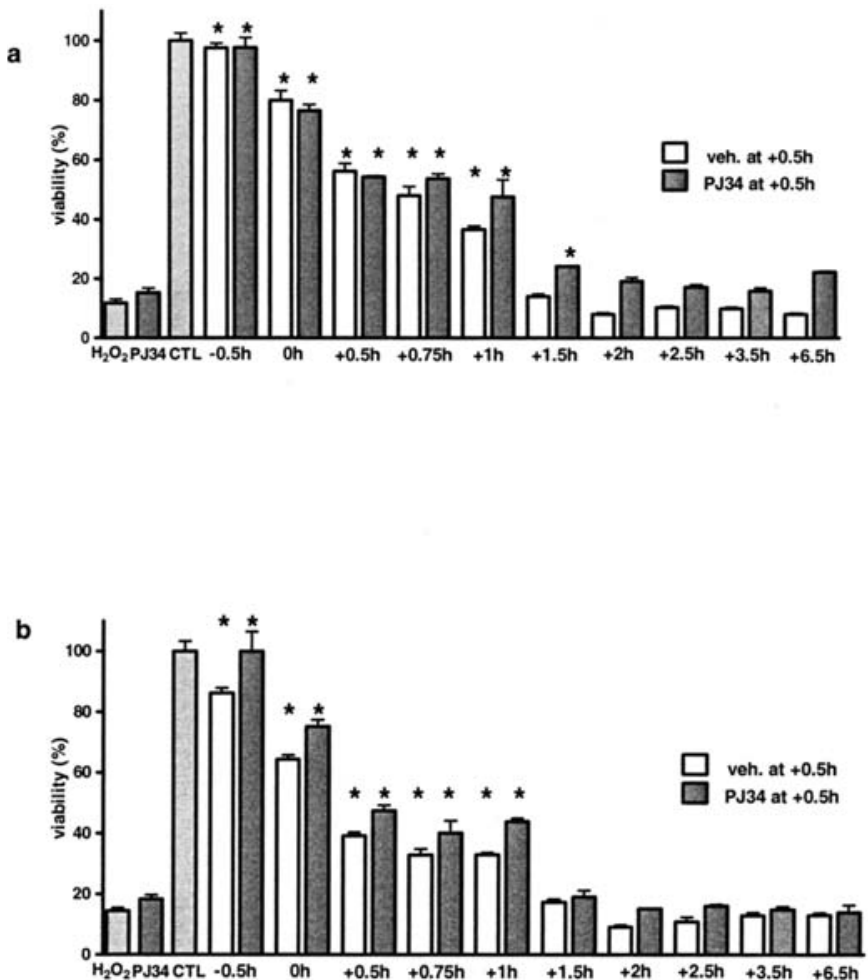

Figure 9. The cytoprotective effect of APB hydrobromide, when applied at various time points. Cardiomyocytes were challenged with $\mathrm{H}_{2} \mathrm{O}_{2}(1000 \mu \mathrm{M})$, 30 min later vehicle or $3 \mu \mathrm{M}$ PJ34 was added, and cell viability was measured $24 \mathrm{~h}$ later by MTT assay. Chloro- (a) or bromo-APB hydrobromide (b) was added at $10 \mu \mathrm{M}$ at the indicated time points. Time points are relative to the application of $\mathrm{H}_{2} \mathrm{O}_{2}$ and are shown in hours (h). Viability values are expressed as percent values of vehicle-treated cells (CTL, control); average \pm SEM values are shown. ${ }^{*} \mathrm{p}<0.05$ compared to the $\mathrm{H}_{2} \mathrm{O}_{2}$ group.

$30 \mu \mathrm{M}$ chloro-APB hydrobromide was comparable to the effect of the potent PARP inhibitor PJ34. However, the cytoprotective effect of APB hydrobromide was more pronounced at $24 \mathrm{~h}$ than that of the PARP inhibitor reference compound. BromoAPB hydrobromide significantly reduced the $\mathrm{H}_{2} \mathrm{O}_{2}$-induced cell death at concentrations $>3 \mu \mathrm{M}$. When $\mathrm{H}_{2} \mathrm{O}_{2}$ induced $75 \%$ reduction in viable cell count, $30 \mu \mathrm{M}$ bromo-APB hydrobromide resulted in $>40 \%$ cell survival, which was significantly higher than what was achieved by PJ34 (Fig. 8b). Combined treatment with $3 \mu \mathrm{M} \mathrm{PJ} 34$ and increasing concentrations of bromo-APB hydrobromide resulted in a dose-dependent increase in cell survival. The combination of APB hydrobromide and PARP inhibitor PJ34 reduced cell loss compared to the single APB treatment at all concentrations of bromo-APB hydrobromide (Fig. 8c). Bromo-APB hydrobromide (30 $\mu \mathrm{M})$ increased cell survival from $25-40 \%$, and the combination with $3 \mu \mathrm{M}$ PJ34 further increased cell survival to $45 \%$. The chloro-APB hydrobromide-induced improvement in cell viability increase was paralleled with significantly reduced LDH release, i.e. lower LDH activity was detected in the cell culture supernatant (Fig. 8d). Combined treatment with PJ34 and APB hydrobromide further reduced the LDH release, reaching nearly baseline levels when $3 \mu \mathrm{M}$ PJ34 and $30 \mu \mathrm{M}$ APB hydrobromide was applied (Fig. 8e).

To study the effective time-frame when APB hydrobromide reduces cytotoxicity, cells were either pretreated

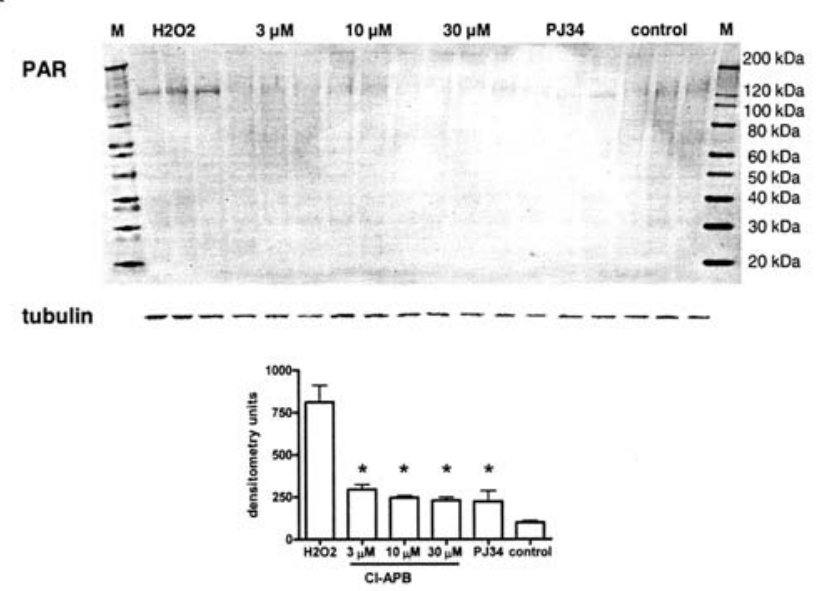

b

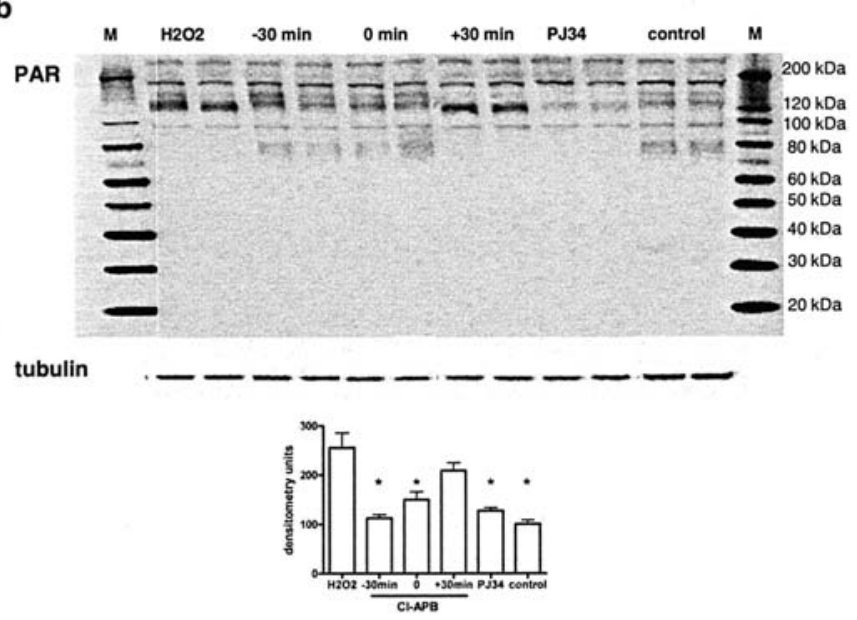

c
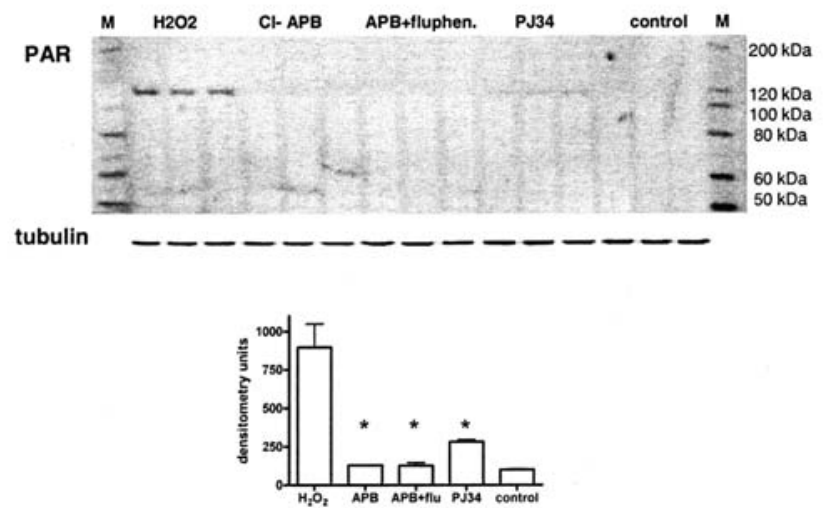

Figure 10. Cl-APB hydrobromide inhibits cellular PARP activation. Cardiomyoblasts were treated with $\mathrm{H}_{2} \mathrm{O}_{2}(500 \mu \mathrm{M})$ for $60 \mathrm{~min}$, and PARP activity was measured by Western blotting for PAR. Cells were pretreated with $\mathrm{Cl}$-APB hydrobromide for $30 \mathrm{~min}$ before the $\mathrm{H}_{2} \mathrm{O}_{2}$ challenge at the indicated concentrations (a), or received Cl-APB-hydrobromide $30 \mathrm{~min}$ prior to $(-30 \mathrm{~min})$, simultaneously with $(0 \mathrm{~min})$ or $30 \mathrm{~min}$ after $(+30 \mathrm{~min})$ the application of $\mathrm{H}_{2} \mathrm{O}_{2}$ (b), or $\mathrm{Cl}$-APB hydrobromide was applied alone and in combination with receptor antagonist fluphenazine (APB+fluphen.) (c). The $\mathrm{H}_{2} \mathrm{O}_{2}$ group received $\mathrm{H}_{2} \mathrm{O}_{2}$ treatment only; the $\mathrm{PJ} 34$ group received $\mathrm{H}_{2} \mathrm{O}_{2}$ and PJ34, and the controls received vehicle only. Representative blots and densitometric analysis results are shown. PAR signals were normalized to tubulin signal and are shown as the mean \pm SEM. ${ }^{*} \mathrm{p}<0.05$ compared to the $\mathrm{H}_{2} \mathrm{O}_{2}$ group.

with the compound, applied simultaneously with or after the $\mathrm{H}_{2} \mathrm{O}_{2}$ challenge at various time points. A significant increase 


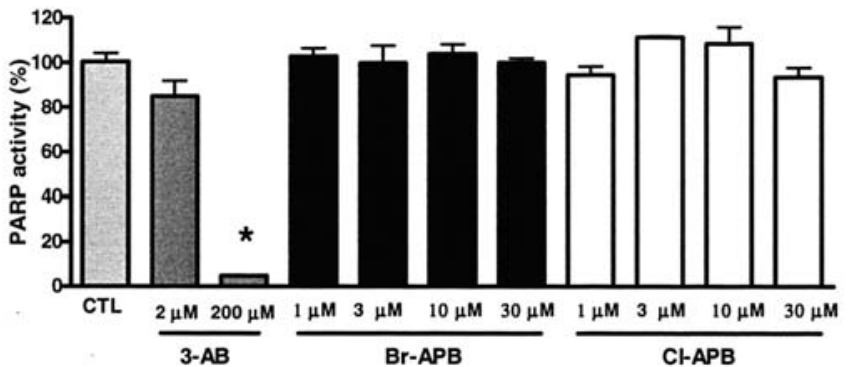

Figure 11. Direct PARP assay. Purified PARP enzyme was pre-incubated with PARP inhibitor 3-aminobenzamide (3-AB), bromo-APB hydrobromide or chloro-APB hydrobromide at the indicated concentrations. PARP was activated with sheared DNA and incubated with labeled NAD substrate. PARP activity was determined by the measurement of incorporated labeled ADP-ribose residues, and was expressed as percent values of maximum PARP activity (vehicle treatment, CTL). Mean \pm SEM values are shown.

was detected in cell survival when peroxide was used prior to or concurrently with the oxidative injury. APB treatment following the oxidative challenge also significantly reduced cell loss at $24 \mathrm{~h}$, when it was applied within the first hour (Fig. 9). The highest cell survival was detected when APBhydrobromide was added 30 min prior to the $\mathrm{H}_{2} \mathrm{O}_{2}$ challenge, and cell survival with later treatments decreased in a timedependent manner. There was no difference in this pattern between bromo- and chloro-APB hydrobromide. Pretreatment with either APB-hydrobromide molecules at $10 \mu \mathrm{M}$ nearly completely restored cell viability when peroxide-induced injury resulted in $80 \%$ cytotoxicity.

$A P B$ hydrobromide is an indirect inhibitor of cellular PARP activity. The cytoprotection of APB hydrobromide was comparable to the protection afforded by the PARP inhibitor PJ34 in the $\mathrm{H}_{2} \mathrm{O}_{2}$-induced cell death model and only moderate improvement was detected when APB molecules were combined with PJ34. To test whether PARP inhibition plays a role in the cytoprotective effect of APB molecules, confluent cultures of $\mathrm{H} 9 \mathrm{c} 2$ cardiomyocytes were treated with $\mathrm{H}_{2} \mathrm{O}_{2}$ to induce PARP activation, and poly(ADP-ribose) (PAR) was detected by Western blotting. $\mathrm{H}_{2} \mathrm{O}_{2}$ induced protein poly(ADP-ribosylation) that could be detected at $120 \mathrm{kDa}$, which corresponds to the auto-ribosylation of PARP. APB hydrobromide decreased poly(ADP-ribosylation) at $120 \mathrm{kDa}$, similar to $\mathrm{PJ} 34$, nearly to baseline, at 3-30 $\mu \mathrm{M}$ concentrations (Fig. 10a). The D1 receptor antagonist fluphenazine had no impact on the PARP inhibitory effect of APB hydrobromide (Fig. 10b), consistent with the notion that the cytoprotective effect of these compounds is due to a chemical mechanism other than interaction with the cellular D1 receptors. This was predicted by the facts that the cardiomyocytes used in the current assay are not known to express functional D1 receptors and the rank order of potency between the currently used D1 compounds did not mirror their rank order of potency $(31,32)$ as D1 receptor agonists. Indeed, pretreatment of the cells with fluphenazine at 10-30 $\mu \mathrm{M}$ (or with chlorpromazine at 3-30 $\mu \mathrm{M}$ ) did not attenuate the cytoprotective effects of these D1 receptor ligands (data not shown). It is noteworthy that the marked cytoprotection that APB hydrobromide provided at $24 \mathrm{~h}$ differed from that of the
PARP inhibitor PJ34, which was only marginally active by this time.

The PARP inhibitory function of APB hydrobromide was also examined in a cell-free system. In a direct PARP assay, when PARP enzyme is activated by sheared DNA, the PARP inhibitor 3-aminobenzamide reduced poly(ADP-ribosylation) in a concentration dependent manner, whereas no significant reduction in PARP activity was detected with either chloroor bromo-APB hydrobromide (Fig. 11).

In conclusion, the findings reported here demonstrate that cytoprotective agents, including novel indirect inhibitors of cellular PARP activation can be identified with a cell-based high-throughput screening method, chloro-APB hydrobromide being one such compound. Cell-based high-throughput screening (as opposed to the traditional process of drug target identification, followed by high-throughput screening of the target enzyme) has recently been proposed by several experts as the method of choice to identify novel lead compounds influencing complex cellular responses where a significant degree of redundancy is present in the system (33-38). The results of the current study lend further support to the validity of this approach. The current method will be applicable for cell-based high-throughput screening of various additional compound libraries, in order to identify bioactive lead molecules and/or to find bioactive functional synergists or functional antagonists of compounds that influence complex cellular responses.

\section{Acknowledgements}

This study was primarily supported by a grant from the Oszkar Asboth project grant of the National Office for Research and Technology (Budapest, Hungary). Additional funding was received from the Hungarian Research Fund (OTKA). C.S. is also supported by the US National Institute of Health, R01 GM66189.

\section{References}

1. Braunwald E and Kloner RA: Myocardial reperfusion: a doubleedged sword? J Clin Invest 76: 1713-1719, 1985.

2. Moens AL, Claeys MJ, Timmermans JP and Vrints CJ: Myocardial ischemia/reperfusion-injury, a clinical view on a complex pathophysiological process. Int J Cardiol 100: 179-190, 2005 .

3. Stephens NG, Parsons A, Schofield PM, Kelly F, Cheeseman K and Mitchinson MJ: Randomised controlled trial of vitamin $\mathrm{E}$ in patients with coronary disease: Cambridge Heart Antioxidant Study (CHAOS). Lancet 347: 781-786, 1996.

4. Chouairi S, Carrie D and Puel J: Myocardial protection with calcium-channel blockers during ischaemia and reperfusion by PTCA. Eur Heart J 16 (suppl H): 3-8, 1995.

5. Narins CR, Miller DP, Califf RM and Topol EJ: The relationship between periprocedural myocardial infarction and subsequent target vessel revascularization following percutaneous coronary revascularization: insights from the EPIC trial. Evaluation of IIb/IIIa platelet receptor antagonist 7E3 in preventing ischemic complications. J Am Coll Cardiol 33: 647-653, 1999.

6. Ferrari R, Pepi P, Ferrari F, Nesta F, Benigno M and Visioli O: Metabolic derangement in ischemic heart disease and its therapeutic control. Am J Cardiol 82: 2K-13K, 1998.

7. Zweier JL: Measurement of superoxide-derived free radicals in the reperfused heart. Evidence for a free radical mechanism of reperfusion injury. J Biol Chem 263: 1353-1357, 1988.

8. Maxwell SR and Lip GY: Reperfusion injury: a review of the pathophysiology, clinical manifestations and therapeutic options. Int J Cardiol 58: 95-117, 1997. 
9. Bianchi C, Wakiyama H, Faro R, et al: A novel peroxynitrite decomposer catalyst (FP-15) reduces myocardial infarct size in an in vivo peroxynitrite decomposer and acute ischemiareperfusion in pigs. Ann Thorac Surg 74: 1201-1207, 2002.

10. Ferrari R, Guardigli G, Mele D, Percoco GF, Ceconi C and Curello S: Oxidative stress during myocardial ischaemia and heart failure. Curr Pharm Des 10: 1699-1711, 2004.

11. Zingarelli B, Cuzzocrea S, Zsengeller Z, Salzman AL and Szabó C: Protection against myocardial ischemia and reperfusion injury by 3-aminobenzamide, an inhibitor of poly (ADP-ribose) synthetase. Cardiovasc Res 36: 205-215, 1997.

12. Zingarelli B, Salzman AL and Szabó C: Genetic disruption of poly (ADP-ribose) synthetase inhibits the expression of Pselectin and intercellular adhesion molecule-1 in myocardial ischemia/reperfusion injury. Circ Res 83: 85-94, 1998.

13. Faro R, Toyoda Y, McCully JD, et al: Myocardial protection by PJ34, a novel potent poly (ADP-ribose) synthetase inhibitor. Ann Thorac Surg 73: 575-581, 2002.

14. Jagtap P and Szabó C: Poly(ADP-ribose) polymerase and the therapeutic effects of its inhibitors. Nat Rev Drug Discov 4: 421-440, 2005.

15. Toth-Zsamboki E, Horvath E, Vargova K, et al: Activation of poly(ADP-ribose) polymerase by myocardial ischemia and coronary reperfusion in human circulating leukocytes. Mol Med 12: 221-228, 2006.

16. Jagtap P, Soriano FG, Virag L, et al: Novel phenanthridinone inhibitors of poly (adenosine 5'-diphosphate-ribose) synthetase: potent cytoprotective and antishock agents. Crit Care Med 30: 1071-1082, 2002.

17. Gilad E, Zingarelli B, Salzman AL and Szabó C: Protection by inhibition of poly (ADP-ribose) synthetase against oxidant injury in cardiac myoblasts in vitro. J Mol Cell Cardiol 29: 2585-2597, 1997

18. Virag L, Scott GS, Antal-Szalmas P, O'Connor M, Ohshima H and Szabó C: Requirement of intracellular calcium mobilization for peroxynitrite-induced poly(ADP-ribose) synthetase activation and cytotoxicity. Mol Pharmacol 56: 824-833, 1999.

19. Alano CC, Kauppinen TM, Valls AV and Swanson RA: Minocycline inhibits poly(ADP-ribose) polymerase-1 at nanomolar concentrations. Proc Natl Acad Sci USA 103: 9685-9690, 2006.

20. Szabó C, Pacher P and Swanson RA: Novel modulators of poly(ADP-ribose) polymerase. Trends Pharmacol Sci 27: 626-630, 2006.

21. Wang H, Liao H, Ochani M, et al: Cholinergic agonists inhibit HMGB1 release and improve survival in experimental sepsis. Nat Med 10: 1216-1221, 2004.

22. Kulkarni DS and Saraf AP: Antagonism of isoproterenolinduced cardiac necrosis in mice by adenosine, dipyridamole and prenylamine. Indian Heart J 30: 220-223, 1978.
23. Rabkin SW: Effect of chlorpromazine on myocardial damage in the calcium paradox. J Cardiovasc Pharmacol 9: 486-492, 1987.

24. McLean KM, Duffy JY, Pandalai PK, et al: Glucocorticoids alter the balance between pro- and anti-inflammatory mediators in the myocardium in a porcine model of brain death. J Heart Lung Transplant 26: 78-84, 2007.

25. Skyschally A, Haude M, Dorge H, et al: Glucocorticoid treatment prevents progressive myocardial dysfunction resulting from experimental coronary microembolization. Circulation 109: 2337-2342, 2004.

26. Tsuchida A, Liu GS, Wilborn WH and Downey JM: Pretreatment with the adenosine A1 selective agonist, 2-chloro-N6cyclopentyladenosine (CCPA), causes a sustained limitation of infarct size in rabbits. Cardiovasc Res 27: 652-656, 1993.

27. Neely CF, DiPierro FV, Kong M, Greelish JP and Gardner TJ: A1 adenosine receptor antagonists block ischemia-reperfusion injury of the heart. Circulation 94: II376-II380, 1996.

28. Yang Z, Cerniway RJ, Byford AM, Berr SS, French BA and Matherne GP: Cardiac overexpression of A1-adenosine receptor protects intact mice against myocardial infarction. Am J Physiol Heart Circ Physiol 282: H949-H955, 2002.

29. Virag L, Salzman AL and Szabó C: Poly(ADP-ribose) synthetase activation mediates mitochondrial injury during oxidant-induced cell death. J Immunol 161: 3753-3759, 1998

30. Zweier JL and Talukder MA: The role of oxidants and free radicals in reperfusion injury. Cardiovasc Res 70: 181-190, 2006.

31. Hartman DS and Lanau F: Diversity of dopamine receptors: new molecular and pharmacological developments. Pol J Pharmacol 49: 191-199, 1997.

32. Zhang A, Neumeyer JL and Baldessarini RJ: Recent progress in development of dopamine receptor subtype-selective agents: potential therapeutics for neurological and psychiatric disorders. Chem Rev 107: 274-302, 2007.

33. Sams-Dodd F: Target-based drug discovery: is something wrong? Drug Discov Today 10: 139-147, 2005.

34. Degterev A, Huang Z, Boyce M, et al: Chemical inhibitor of nonapoptotic cell death with therapeutic potential for ischemic brain injury. Nat Chem Biol 1: 112-119, 2005.

35. Williams M: Target validation. Curr Opin Pharmacol 3: 571-577, 2003.

36. Dormán G, Krajcsi P, Puskás L, et al: Recent advances in chemical genomics. Front Med Chem 3: 503-550, 2006.

37. Dormán G and Darvas F: Utilizing small molecules in chemical genomics: toward HT approaches. In: Chemical Genomics. Darvas F, Guttman A and Dormán G (eds). Marcel Dekker, New York, Basel, pp137-197, 2004.

38. Butcher EC: Can cell systems biology rescue drug discovery? Nat Rev Drug Discov 4: 461-467, 2005. 